\title{
27. THERMAL CONDUCTIVITY, DENSITY, AND SONIC VELOCITY MEASUREMENTS OF SAMPLES OF ANHYDRITE AND HALITE FROM SITES 225 AND 227
}

\author{
J. Wheildon and T. R. Evans, Geophysics Department, Imperial College, London, \\ and \\ R. W. Girdler, School of Physics, The University, Newcastle upon Tyne
}

\section{INTRODUCTION}

Samples of anhydrite were taken from Sites 225 and 227 and halite from Site 227 for thermal conductivity, density, and sonic velocity measurements. The anhydrite occurs at a depth of 176 meters at Site 225, and samples were taken at 203.5 and 222.0 meters. At Site 227, the evaporite sequence starts at a depth of 226 meters and samples of anhydrite were taken at $227.7,342.8$, and 343.6 meters and samples of halite at $238.5,239.4,263.8$, and 264.5 meters.

There are several sets of temperature data available from oil company boreholes (Girdler, 1970) which include measurements in the evaporites. As no thermal conductivity measurements are available for any of the Red Sea evaporites, it was thought desirable to take a few samples from Sites 225 and 227 to see if the values used by Girdler (1970) are reasonable. Also, it was considered that the data might be of value in the future for use with temperatures from other Red Sea exploration wells. Unfortunately, it was not possible to make temperature measurements in these rocks during drilling operations aboard D/V Glomar Challenger as they are too hard to penetrate with the heat flow probe.

Densities and sonic velocities are of value for the interpretation of gravity and seismic refraction data. In the Red Sea, there is some evidence that the width of the axial positive Bouguer anomaly is distorted by the thicknesses of evaporites towards the margins. The interpretation of the anomalies associated with the sediments is therefore of considerable importance. There are a number of seismic refraction profiles in the Red Sea (Drake and Girdler, 1964; Davies and Tramontini, 1970), both in shallow and deep water, and sonic velocity measurements are useful for the interpretation of the nature of the near-bottom refractors.

\section{THERMAL CONDUCTIVITIES}

Several discs (diameter $3.5 \mathrm{~cm}$ and thickness about 1 $\mathrm{cm}$ ) were machined from the samples and hand lapped with fine corundum powder. Thermal conductivities were measured using the divided bar technique (e.g., Jessop, 1970), the specimens being subjected to a uniaxial pressure of 70 $\mathrm{kg} / \mathrm{cm}^{2}$ and a temperature drop of $5^{\circ} \mathrm{C}$, the mid point temperature being $24^{\circ} \mathrm{C}$. The anhydrite specimens were water saturated and a glycerine and water film was used to improve thermal contact with the divided bar. These conditions, of course, were not fulfilled for the halite specimens. The accuracy is considered to be about 1
TABLE 1

Thermal Conductivities

\begin{tabular}{|c|c|c|c|c|}
\hline Sample & $\begin{array}{l}\text { Depth } \\
\text { (m) }\end{array}$ & $\begin{array}{c}\text { Thick- } \\
\text { ness } \\
(\mathrm{mm})\end{array}$ & & $\begin{array}{l}\mathrm{K} \text { at } 24^{\circ} \mathrm{C} \\
\left.\mathrm{m}^{-1} \mathrm{~K}^{-1}\right)\end{array}$ \\
\hline \multicolumn{5}{|l|}{ Anhydrite: } \\
\hline $225-27-1,50-53 \mathrm{~A}$ & 203.51 & 10.28 & & 4.484 \\
\hline B & 203.51 & 3.32 & & 4.417 \\
\hline $225-29-1,97-102 \mathrm{~A}$ & 221.99 & 9.29 & & 4.514 \\
\hline B & 221.99 & 9.21 & & 4.689 \\
\hline $\mathrm{C}$ & 221.99 & 3.51 & & 4.501 \\
\hline \multirow[t]{2}{*}{$\mathrm{D}$} & 221.99 & 4.37 & & 4.476 \\
\hline & & & Mean & $\begin{array}{c}4.513 \pm 0.084 \\
(N=6)\end{array}$ \\
\hline $227-30-2,22-29$ & 227.75 & 9.84 & & 4.966 \\
\hline $227-44-2,28-35$ & 342.81 & 9.90 & & 4.853 \\
\hline \multirow[t]{2}{*}{$227-44-2,106-110$} & 343.58 & 10.46 & & 5.636 \\
\hline & & & Mean & $\begin{array}{c}5.152 \pm 0.346 \\
(N=3)\end{array}$ \\
\hline \multicolumn{5}{|l|}{ Halite } \\
\hline $227-31-3,50-57 \mathrm{~B}$ & 238.53 & 10.17 & & 5.116 \\
\hline $\mathrm{C}$ & 238.53 & 10.12 & & 5.079 \\
\hline $227-31-3,137-142 \mathrm{~A}$ & 239.39 & 10.10 & & $(4.601)$ \\
\hline B & 239.39 & 9.99 & & 5.079 \\
\hline $227-34-2,27-32 \mathrm{~A}$ & 245.79 & 10.08 & & 5.267 \\
\hline B & 245.79 & 10.27 & & 5.217 \\
\hline \multirow{3}{*}{$227-34-2,96-100 \mathrm{~A}$} & 264.48 & 10.26 & & 4.745 \\
\hline & 264.48 & 10.20 & & 5.405 \\
\hline & & & Mean & $\begin{array}{c}5.130 \pm 0.191 \\
(N=7)\end{array}$ \\
\hline
\end{tabular}

percent for the anhydrite specimens and somewhat less for the halite specimens. The results are given in Table 1.

For the anhydrite, the mean thermal conductivity for all specimens from both sites is $4.73 \pm 0.37 \mathrm{Wm}^{-1} \mathrm{~K}^{-1}$, but there appears to be a significant difference in the means for the two sites. Clark (1966) gives the means for four sets of data, each containing three measurement: these are 5.61, $4.90,5.74$, and $5.40 \mathrm{Wm}^{-1} \mathrm{~K}^{-1}$. The values for the Red Sea, especially Site 225 , would appear to be a little low, but the value for Site 227 is within the range of means quoted by Clark (1966). However, it is emphasized that there are too few data available for anhydrite to enable comparisons to be meaningful.

For halite, the mean conductivity value (Site 227) is $5.13 \pm 0.19(\mathrm{~N}=7)$. This compares with a value of 5.64 $\mathrm{Wm}^{-1} \mathrm{~K}^{-1}$ from the empirical relationship given by Girdler (1970). All seven measurements, therefore, are somewhat low, but because of the paucity of data, this may or may not be meaningful. 


\section{DENSITIES}

Densities were measured by weighing the anhydrite specimens in air and water and the halite specimens in air and carbon tetrachloride. The results are given in Table 2.

It is seen that the mean density of the anhydrite at Site 227 is slightly higher than the mean for Site 225 (cf. the conductivities). The mean for all specimens is $2.86 \pm 0.04$ $\mathrm{g} / \mathrm{cm}^{3}(\mathrm{~N}=9)$. Only two values seem to be available in the literature, i.e., $2.963 \mathrm{~g} / \mathrm{cm}^{3}$ for pure anhydrite (Clark, 1965) and $2.75 \mathrm{~g} / \mathrm{cm}^{3}$ (Kaye and Laby, 1962).

\begin{tabular}{|c|c|c|c|}
\hline Sample & $\begin{array}{l}\text { Depth } \\
\text { (m) }\end{array}$ & & $\begin{array}{l}\text { Density } \\
\left(\mathrm{g} / \mathrm{cm}^{3}\right)\end{array}$ \\
\hline \multicolumn{4}{|l|}{ Anhydrite: } \\
\hline $225-27-1,50-53 \mathrm{~A}$ & 203.51 & & 2.821 \\
\hline B & 203.51 & & 2.783 \\
\hline $225-29-1,97-102 \mathrm{~A}$ & 221.99 & & 2.837 \\
\hline B & 221.99 & & 2.873 \\
\hline $\mathrm{C}$ & 221.99 & & 2.858 \\
\hline \multirow[t]{2}{*}{$\mathrm{D}$} & 221.99 & & 2.830 \\
\hline & & Mean & $2.834 \pm 0.028(\mathrm{~N}=6)$ \\
\hline $227-30-2,22-29$ & 227.75 & & 2.908 \\
\hline $227-44-2,28-35$ & 342.81 & & 2.878 \\
\hline \multirow[t]{2}{*}{$227-44-2,106-110$} & 343.58 & & 2.929 \\
\hline & & Mean & $2.905 \pm 0.021(\mathrm{~N}=3)$ \\
\hline \multicolumn{2}{|c|}{ Overall Mean (Sites 225 and 227) } & & $2.857 \pm 0.043(\mathrm{~N}=9)$ \\
\hline \multicolumn{4}{|l|}{ Halite: } \\
\hline $227-31-3,50-57 \mathrm{~B}$ & 238.53 & & 2.143 \\
\hline $\mathrm{C}$ & 238.53 & & 2.160 \\
\hline $227-31-3,137-142 \mathrm{~A}$ & 239.39 & & 2.141 \\
\hline B & 239.39 & & 2.158 \\
\hline $227-34-2,27-32 \mathrm{~A}$ & 245.79 & & 2.165 \\
\hline B & 245.79 & & 2.148 \\
\hline \multirow{3}{*}{$\begin{array}{r}227-34-2,96-100 \mathrm{~A} \\
\mathrm{~B}\end{array}$} & 264.48 & & 2.118 \\
\hline & 264.48 & & 2.128 \\
\hline & & Mean & $2.145 \pm 0.015(\mathrm{~N}=8)$ \\
\hline
\end{tabular}

For halite, the mean for eight specimens of $2.145 \pm$ $0.015 \mathrm{~g} / \mathrm{cm}^{3}$ is quite close to the value of $2.163 \mathrm{~g} / \mathrm{cm}^{3}$ given for pure halite (Clark, 1966; Kaye and Laby, 1962).

\section{SONIC VELOCITIES}

The sonic velocities were measured using an Ultrasonic Materials Tester Type UCT2/1822 by courtesy of Mr. Robert Best of the Engineering Geology Section of Imperial College, London. The results are given in Table 3. Each specimen was measured twice, and it is seen that the repeatability is not good. This is partly due to the smallness of the specimens (machined for the thermal conductivity apparatus). The means of the two measurements are used.

The mean sonic velocity for the anhydrite $(4.9 \pm 0.3$ $\mathrm{km} / \mathrm{s})$ is higher than that for Site $225(4.6 \pm 0.7 \mathrm{~km} / \mathrm{s})$ although this may not be significant. It is of interest that the thermal conductivity, density, and sonic velocity are all higher at Site 227. Two sonic velocities for anhydrite are quoted in Clark (1966); these are 4.1 and $5.00 \mathrm{~km} / \mathrm{s}$.

The mean sonic velocity for the halite (Site 227) is $4.2 \pm$ $0.4 \mathrm{~km} / \mathrm{s}$ and is considerably smaller than that for the anhydrite. The value quoted in Clark (1966) is 4.4 to 6.5 $\mathrm{km} / \mathrm{s}$ for salt, carnallite, and sylvite.

\section{REFERENCES}

Clark, S. P., 1966. Handbook of Physical Constants: Geol. Soc. Am. Mem. 97.

Davies, D. and Tramontini, C., 1970. The deep structure of the Red Sea: Phil. Trans. Roy. Soc. London, A., v. 267, p. 181-189.

Drake, C. L. and Girdler, R. W., 1964. A Geophysical Study of the Red Sea: Geophys. J. Roy. Astron. Soc. London, v. 8 , p. $473-495$.

Girdler, R. W., 1970. A review of Red Sea heat flow: Phil. Trans. Roy. Soc. London, A, v. 267, p. 191-203.

Jessop, A. M., 1970. The effect of environment on divided bar measurements: Tectonophysics, v. 10, p. 39-49.

Kaye, G. W. C. and Laby, T. H., 1962. Tables of Physical and Chemical Constants: London (Longmans). 
TABLE 3

Sonic Velocities

\begin{tabular}{|c|c|c|c|c|c|c|c|c|}
\hline \multirow{2}{*}{$\begin{array}{l}\text { Sample } \\
\text { Anhydrite: }\end{array}$} & \multirow[t]{2}{*}{$\begin{array}{l}\text { Depth } \\
\text { (m) }\end{array}$} & \multirow[t]{2}{*}{$\begin{array}{c}\text { Thickness } \\
\text { (mm) }\end{array}$} & \multicolumn{2}{|c|}{ Time $(\mu \mathrm{s})$} & \multicolumn{2}{|c|}{$\begin{array}{l}\text { Mean Velocity } \\
(\mathrm{km} / \mathrm{s})\end{array}$} & \multicolumn{2}{|c|}{ Mean Velocity $(\mathrm{km} / \mathrm{s})$} \\
\hline & & & & & & & & \\
\hline $225-27-1,50-53 \mathrm{~A}$ & 203.51 & 10.31 & 2.1 & 1.9 & 4.91 & 5.43 & & 5.17 \\
\hline $225-29-1,97-102 \mathrm{~A}$ & 221.99 & 9.32 & 2.9 & 2.3 & 3.21 & 4.05 & & 3.63 \\
\hline \multirow[t]{2}{*}{ B } & 221.99 & 9.19 & 1.9 & 1.7 & 4.84 & 5.41 & & $\underline{5.12}$ \\
\hline & & & & & & & Mean & $4.64 \pm 0.71(\mathrm{~N}=3)$ \\
\hline $227-30-2,22-29$ & 227.75 & 9.83 & 2.0 & 2.2 & 4.91 & 4.47 & & 4.69 \\
\hline $227-44-2,28-35$ & 342.81 & 9.96 & 2.2 & 2.0 & 4.53 & 4.98 & & 4.75 \\
\hline \multirow[t]{2}{*}{$227-44-2,106-110$} & 343.58 & 10.49 & 2.1 & 1.8 & 4.99 & 5.83 & & 5.41 \\
\hline & & & & & & & Mean & $4.95 \pm 0.33(\mathrm{~N}=3)$ \\
\hline \multicolumn{2}{|c|}{ Overall Mean (Sites 225 and 227) } & & & & & & & $4.80 \pm 0.58(\mathrm{~N}=6)$ \\
\hline \multicolumn{9}{|l|}{ Halite: } \\
\hline $227-31-3,50-57 \mathrm{~B}$ & 238.53 & 10.26 & 2.1 & 2.4 & 4.89 & 4.28 & & 4.58 \\
\hline $\mathrm{C}$ & 238.53 & 10.21 & 2.3 & 2.2 & 4.44 & 4.64 & & 4.54 \\
\hline $227-31-3,137-142 B$ & 239.39 & 10.18 & 2.2 & 2.6 & 4.63 & 3.92 & & 4.27 \\
\hline $227-34-2,27-32 \mathrm{~A}$ & 245.79 & 10.13 & 3.0 & 2.8 & 3.38 & 3.62 & & 3.50 \\
\hline B & 245.79 & 10.31 & 2.6 & 2.3 & 2.97 & 4.48 & & 4.22 \\
\hline $227-34-2,96-100 \mathrm{~A}$ & 264.48 & 10.34 & 2.4 & 2.3 & 4.31 & 4.49 & & 4.40 \\
\hline \multirow[t]{2}{*}{ B } & 264.48 & 10.26 & 2.8 & 2.6 & 3.66 & 3.95 & & $\underline{3.80}$ \\
\hline & & & & & & & Mean & $4.20 \pm 0.37(\mathrm{~N}=7)$ \\
\hline
\end{tabular}

